\title{
Author Correction: Single cell transcriptome analysis of developing arcuate nucleus neurons uncovers their key developmental regulators
}

Christian Huisman, Hyeyoung Cho, Olivier Brock, Su Jeong Lim (D), Sung Min Youn (D, Younjung Park, Sangsoo Kim, Soo-Kyung Lee (D), Alessio Delogu \& Jae W. Lee (1)

Correction to: Nature Communications https://doi.org/10.1038/s41467-019-11667-y, published online 16 August 2019.

The original version of this Article contained an error in Fig. 4, where the transcription factors enriched in E15 developing ARC neurons were not correctly listed. The correct version of Fig. 4 is:

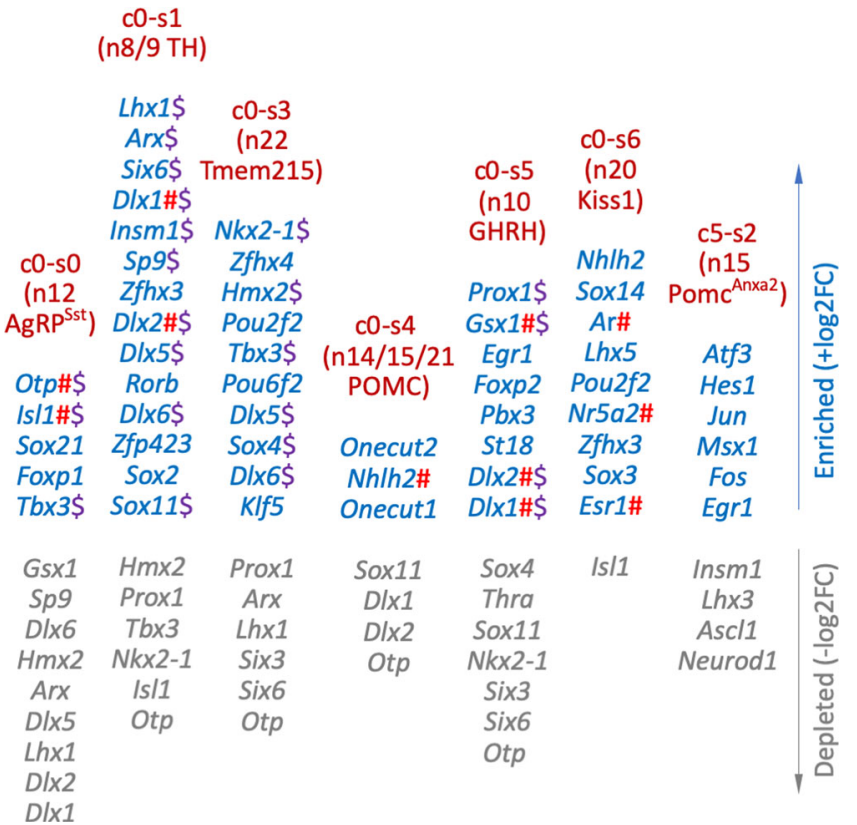


which replaces the previous incorrect version:

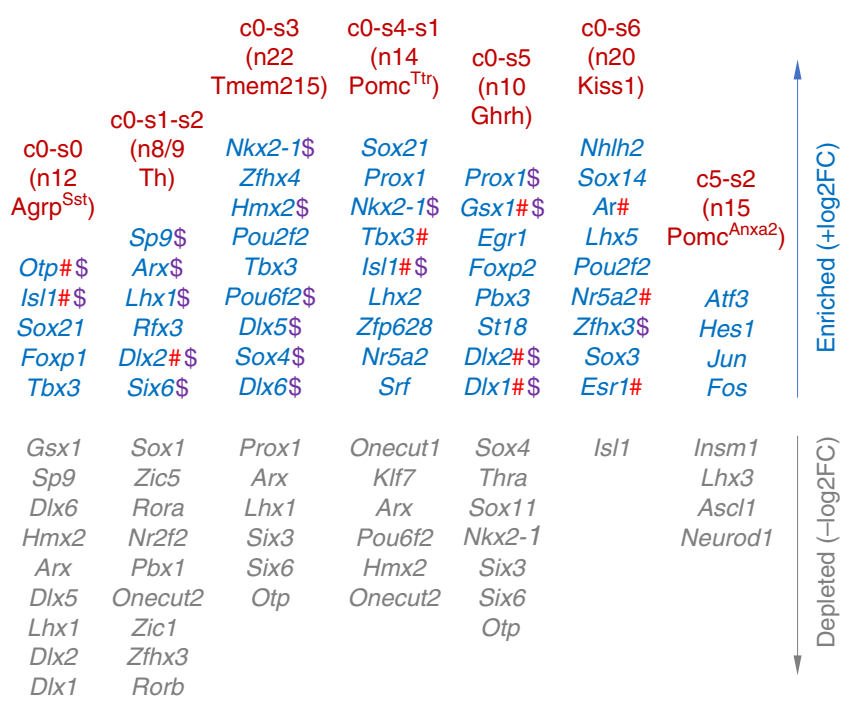

This has been corrected in both the PDF and HTML versions of the Article.

The original version of this Article contained multiple errors in the Figure legend, Results and Discussion sections related to Fig. 4, which was incorrect. This has been corrected in both the PDF and HTML versions of the Article.

Published online: 10 March 2020

\begin{abstract}
(c) (i) Open Access This article is licensed under a Creative Commons Attribution 4.0 International License, which permits use, sharing, adaptation, distribution and reproduction in any medium or format, as long as you give appropriate credit to the original author(s) and the source, provide a link to the Creative Commons licence, and indicate if changes were made. The images or other third party material in this article are included in the article's Creative Commons licence, unless indicated otherwise in a credit line to the material. If material is not included in the article's Creative Commons licence and your intended use is not permitted by statutory regulation or exceeds the permitted use, you will need to obtain permission directly from the copyright holder. To view a copy of this licence, visit http://creativecommons.org/licenses/by/4.0/.
\end{abstract}

(c) The Author(s) 2020 